\title{
Biomineralization Mediated by Ureolytic Bacteria Applied to Water Treatment: A Review
}

\author{
Dayana Arias $^{1,2}$ (1) , Luis A. Cisternas ${ }^{2,3}$ (1) and Mariella Rivas ${ }^{1,3, *}$ \\ 1 Laboratory of Algal Biotechnology \& Sustainability, Faculty of Marine Sciences and Biological Resources, \\ University of Antofagasta, Antofagasta 1240000, Chile; dayana.arias.t@gmail.com \\ 2 Department of Chemical Engineering and Mineral Process, University of Antofagasta, \\ Antofagasta 1240000, Chile; luis.cisternas@uantof.cl \\ 3 Science and Technology Research Center for Mining CICITEM, Antofagasta 1240000, Chile \\ * Correspondence: mariella.rivas@uantof.cl
}

Academic Editor: Jolanta Prywer

Received: 6 October 2017; Accepted: 4 November 2017; Published: 17 November 2017

\begin{abstract}
The formation of minerals such as calcite and struvite through the hydrolysis of urea catalyzed by ureolytic bacteria is a simple and easy way to control mechanisms, which has been extensively explored with promising applications in various areas such as the improvement of cement and sandy materials. This review presents the detailed mechanism of the biominerals production by ureolytic bacteria and its applications to the wastewater, groundwater and seawater treatment. In addition, an interesting application is the use of these ureolytic bacteria in the removal of heavy metals and rare earths from groundwater, the removal of calcium and recovery of phosphate from wastewater, and its potential use as a tool for partial biodesalination of seawater and saline aquifers. Finally, we discuss the benefits of using biomineralization processes in water treatment as well as the challenges to be solved in order to reach a successful commercialization of this technology.
\end{abstract}

Keywords: biomineralization; calcite; seawater; wastewater; heavy metals removal; biodesalination

\section{Introduction}

Without water, there is no life and, in recent years, this resource is increasingly scarce. Various factors such as climate change, droughts and population increase contribute to its scarcity [1]. Although the earth's surface consists of 70\% water, only 3\% corresponds to freshwater. In addition, a significant part of that percentage is found in ice caps and glaciers, consequently only $1 \%$ of the surface freshwater is usable. Efficiency in water use can significantly increase if the capacity to reuse it increases by using new and improved technologies. In the case of seawater, desalination emerges as an alternative to extract salt and other polluting elements from it, turning it into water suitable for human consumption, or for productive uses such as agriculture and mining, among others. Desalination is identified as a safe source of water that guarantees a stable supply as compared with the variability of natural sources and the scarcity of this resource in the basins. However, the application of chemical methods generates waste that affects the environment [2,3].

In contrast, the use of new biotechnological tools could favor the recycle of wastewater and improve the quality of seawater and freshwater. Such is the case of biomineralization, a process that is mediated by bacteria and other organisms for the formation of minerals from ions present in the surrounding environment. A particular form of biomineralization is microbiological carbonates precipitation (MICP), and is defined as the process involving the formation of minerals mediated by living organisms as a result of the cellular activity that promotes the physicochemical conditions required to carry out the formation and growth of the biominerals [4]. There is a great variety of structures and, in nature, more than 60 types of biological minerals have been described [5]. From 
an evolutionary point of view, this process is generated mainly from bacterial activity. Bacteria are capable of inducing mineral precipitation through three types of mechanisms [6].

i) Biologically controlled mineralization consists of cellular activities specifically aimed at the formation of minerals [6-8]. Organisms direct the synthesis of minerals in a specific part of the cell but only under certain conditions. For example, the formation of magnetite by magnetotactic bacteria. The magnetotactic bacteria have control over the mineral phase and its biosynthesis in the magnetosome, at the level of genes.

ii) Biologically influenced mineralization corresponds to the passive precipitation of minerals due to the interaction between the environment and its chemical and compound changes present in the cellular surface as a result of the bacterial metabolic activity, for example extracellular polymeric substances associated with biofilms [7-10]. In this type of biomineralization, the biominerals are secreted due to the metabolism of the microorganisms, and the system has very little control over the minerals that have been deposited. There are a large number of bacteria capable of biologically inducing the extracellular precipitation of a wide range of minerals, involving the geochemical activity responsible for mineral deposits in terrestrial evolution.

iii) Biologically induced mineralization, which corresponds to the chemical modification of an environment mediated by the biological activity producing oversaturation and precipitation of minerals $[6,8,11]$.

In the third case, the bacteria contribute actively to the formation of minerals, but also in a passive way, through cellular structures that act as nucleation sites [12-15]. In addition, bacteria can induce heterogeneous nucleation of minerals, given not only by a surface with a lower energetic barrier to minerals precipitation, but also with a stereochemical structuring of the mineral components. However, there may be a combination of the three different processes active in the same system [8]. Some studies highlight the role of the extracellular polymer substances (EPS). These exopolymers and the biofilms are commonly dominated by negatively charged polysaccharides [16] and may contribute to the precipitation of minerals in different forms;

i) By trapping positively charged cations in negatively charged sites of the EPS that act as a tempering for crystal nucleation [9,17].

ii) By entrapment of crystal seeds that act as a nuclei for the heterogeneous precipitation of minerals $[9,14]$.

Within this point, biological processes that increase the $\mathrm{pH}$ of the medium and create the oversaturated conditions necessary for its precipitation have been identified $[4,18]$. Different bacteria with varied metabolisms are able to precipitate biominerals from carbonates [19-23], oxides [24,25], sulfates $[26,27]$ and phosphates $[28,29]$. This review focuses on biomineralization mediated by ureolytic bacteria. The best-studied mechanism is the precipitation of calcium carbonate by ureolysis, in which the bacteria metabolize urea through an intracellular urease enzyme, producing $\mathrm{HCO}_{3}{ }^{-}$and $\mathrm{NH}_{3}$. The latter is converted into $\mathrm{NH}_{4}{ }^{+}$, alkalinizing the medium, and the $\mathrm{HCO}_{3}{ }^{-}$is converted into $\mathrm{CO}_{3}{ }^{2-}[30,31]$. When any calcium ion is present and oversaturation of calcite occurs, precipitation of calcium carbonate is induced [32].

\section{Ureolytic Metabolism}

The urease enzyme is present in a great diversity of microorganisms (urea amidohydrolase; EC 3.5.1.5) reviewed in [6,8,33] enabling the cell to use urea as a source of nitrogen [34]. Sporosarcina pasteurii ATCC11859, formally Bacillus pasteurii [35], is the terrestrial ureolytic bacterium most used as an example of MICP and presents an active intracellular urease $[4,11]$.

The water treatment processes mediated by ureolytic bacteria described in this review are based on the general mechanism of carbonates biological precipitation, which basically consists of the microorganisms' ability to alkalize the surrounding environment according to the physiological activities they perform. These bacteria are widely distributed in nature and their role is to catalyze 
the hydrolysis of urea to produce carbonic acid and ammonium $[8,30,36]$. These products, in solution, have as final result to induce a change of $\mathrm{pH}$ in the medium (Ecs. 1-4) [30]:

$$
\begin{gathered}
\mathrm{CO}\left(\mathrm{NH}_{2}\right)_{2}+\mathrm{H}_{2} \mathrm{O} \stackrel{\text { urease }}{\rightarrow} \mathrm{NH}_{3}+\mathrm{CO}\left(\mathrm{NH}_{2}\right) \mathrm{OH} \\
\mathrm{CO}\left(\mathrm{NH}_{2}\right) \mathrm{OH}+\mathrm{H}_{2} \mathrm{O} \rightarrow \mathrm{NH}_{3}+\mathrm{H}_{2} \mathrm{CO}_{3} \\
\mathrm{H}_{2} \mathrm{CO}_{3} \leftrightarrow \mathrm{HCO}_{3}^{-}+\mathrm{H}^{+} \\
2 \mathrm{NH}_{3}+2 \mathrm{H}_{2} \mathrm{O} \rightarrow 2 \mathrm{NH}_{4}^{+}+2 \mathrm{OH}^{-}
\end{gathered}
$$

The increase in $\mathrm{pH}$ leads to an adjustment of the bicarbonate equilibrium to form carbonate ions, further favoring the formation of $\mathrm{CO}_{3}{ }^{2-}$ from $\mathrm{HCO}_{3}{ }^{-}$[37]. A high carbonate concentration induces $\mathrm{CaCO}_{3}$ precipitation around the cells and the presence of calcium ions in the surrounding environment (Ecs. 5-7) [38].

$$
\begin{gathered}
2 \mathrm{HCO}_{3}^{-}+2 \mathrm{H}^{+}+2 \mathrm{NH}_{3}+2 \mathrm{OH}^{-} \leftrightarrow 2 \mathrm{CO}_{3}^{2-}+2 \mathrm{NH}_{4}^{+}+2 \mathrm{H}_{2} \mathrm{O} \\
\mathrm{Ca}^{2+}+\text { Cell } \rightarrow \text { Cell : } \mathrm{Ca}^{2+} \\
\text { Cell : } \mathrm{Ca}^{2+}+\mathrm{CO}_{3}^{2-} \rightarrow \text { Cell }: \mathrm{CaCO}_{3}
\end{gathered}
$$

Under natural conditions, the precipitation of carbonates occurs very slowly. In this sense, microorganisms would act as catalysts in the carbonate formation process. Carbonates, especially calcite $\left(\mathrm{CaCO}_{3}\right)$ and dolomite $\left(\mathrm{CaMg}\left(\mathrm{CO}_{3}\right)_{2}\right)$ are found as limestones on the Earth's surface, representing an important carbon stock in the lithosphere [38,39].

The mechanisms through which the biological precipitation of carbonates occurs are not fully described. However, three mechanisms have been proposed to explain this process [40]: i) Biomineralization occurs as a bioproduct of the microbial metabolism; ii) Extracellular molecules are involved in the carbonate mineralization process; iii) A nucleation process of carbonates occurs in the cell wall of microorganisms. Based on the latter proposed mechanism, the role of microorganisms in creating an alkaline environment through various physiological activities is known. Under these circumstances, the bacterial surface plays an important role in the precipitation of carbonates due to the presence of various negatively charged groups at neutral $\mathrm{pH}$, positive ions can bind to the bacterial surface favoring heterogeneous nucleation [40]. The microbiological precipitation of minerals has several technological applications, such as the restoration of limestone monuments and statues, biocement production, improvement of soil quality and removal of soluble pollutants such as heavy metals and radioactive elements [30]. Additionally, this process promoted specifically by the ureolytic capacity of bacterial species also allows the removal of secondary ions such as calcium and magnesium present in wastewater [33,41,42] and in seawater [43]. Furthermore, the precipitation of calcium carbonates mediated by ureolytic bacteria is widely described in the literature, mainly under the application of soil biocementation $[8,44,45]$. Other uses are related to carbon dioxide capture and remediation of soils and water $[40,46]$.

\section{Types of Biominerals Produced by Ureolytic Bacteria}

Compared with inorganically produced minerals, biominerals often have their own specific properties including unique size, crystallinity, isotopic and trace element compositions [47]. There are several types of biominerals such as organic crystals, oxides, hydroxides, sulfates, sulfides, chlorides, phosphates and carbonates [39,48-50] highlighting calcium carbonates. Calcium carbonate exists in three different crystalline structures: vaterite, calcite and aragonite, and in two hydrated crystalline phases: monohydrocalcite $\left(\mathrm{CaCO}_{3} \cdot \mathrm{H}_{2} \mathrm{O}\right)$ and ikaite $\left(\mathrm{CaCO}_{3} \cdot 6 \mathrm{H}_{2} \mathrm{O}\right)$, and various amorphous phases (ACC) $[8,40]$. Although the crystalline structures of carbonates due to bacterial activity are clear, little is known about the causes of the selection of different polymorphisms during bacterial biomineralization. 
Although there are studies suggesting that the amount and morphology of calcium carbonate minerals depend on oversaturation, temperature, $\mathrm{pH},\left[\mathrm{Ca}^{2+}\right] /\left[\mathrm{CO}_{3}{ }^{2-}\right]$ ratio [51] and the concentration of urea [42]. Hammes et al. [33] during a study of ureolytic microbial calcium carbonate $\left(\mathrm{CaCO}_{3}\right)$ precipitation by bacterial isolates collected from different environmental samples, morphological differences were observed in the large $\mathrm{CaCO}_{3}$ crystal aggregates precipitated within bacterial colonies grown on agar. This fact was verified at our laboratory confirming that different halophilic and halotolerant ureolytic bacterial strains isolated from the Atacama Salar produce calcium carbonate crystals with different polymorphism when they were cultivated in nutrient broth (NB) supplemented with $\mathrm{Ca}^{2+}$ (Figure 1). This is exactly what Uad et al. [50] described: biominerals present a variety of forms from spheres, hemispheres and pseudopolyhedral forms, which appeared either in isolation or in group.

Although calcium carbonates are the most studied crystals, ureolytic bacteria are capable of forming different types of crystals depending on the medium in which they are (Table 1). For example, vaterite is found to be in a lower percentage, metastable or in the transitional phase of calcite [8] and it has been described that it depends on the concentration of EPS and the organic matter that would influence its formation, which could be stabilized in the presence of certain organics [8,52]. The maturation of $\mathrm{CaCO}_{3}$ from vaterite to calcite follows the Ostwald's step rule, where metastable forms nucleate and then are replaced with more stable forms, with this sequential formation in time is also known as paragenesis [53]. However, the mechanisms of initial nucleation that are influenced by bacterial growth conditions, the presence of organic matter such as EPS, saturation conditions of the fluid and crystals maturation are still not well understood $[8,54]$. The size of crystals is also a key factor. The $\mathrm{CaCO}_{3}$ crystals precipitated by ureolytic metabolism are generally large and less soluble than those precipitated under abiotic conditions [51,55].

Table 1. Examples of crystals produced by ureolytic bacteria.

\begin{tabular}{|c|c|c|c|}
\hline Bacterial Species & Crystal & Aplication & Reference \\
\hline Enterobacter cloacae & Calcite & $\begin{array}{l}\text { Heavy metals } \\
\text { bioremediation }\end{array}$ & Kang et al. [56] \\
\hline Bacillus sp. & $\begin{array}{l}\text { Calcitemagnesium carbonate trihydrate } \\
\qquad\left(\mathrm{MgCO}_{3} \cdot 3 \mathrm{H}_{2} \mathrm{O}\right)\end{array}$ & Biocementation & Cheng et al. [57] \\
\hline $\begin{array}{l}\text { Sporosarcina } \\
\text { ginsengisoli }\end{array}$ & As(III)-calcite calcite, aragonite and vaterite & As(III) remediation & Achal et al. [58] \\
\hline Halomonas sp. & $\begin{array}{c}\text { calcite, vaterite and aragonite along with } \\
\text { calcite-strontianite }\left(\mathrm{SrCO}_{3}\right) \text { solid } \\
\text { Halite }(\mathrm{NaCl})\end{array}$ & Sr remediation & Achal et al. [59] \\
\hline $\begin{array}{l}\text { Rhodococcus } \\
\text { erythropolis }\end{array}$ & $\begin{array}{c}\text { Monohydrocalcite }\left(\mathrm{CaCO}_{3} \cdot \mathrm{H}_{2} \mathrm{O}\right) \\
\text { Struvite } \\
\text { Anhydrite }\end{array}$ & $\begin{array}{l}\text { Calcium and magnesium } \\
\text { precipitation from sea water }\end{array}$ & Arias et al. [43] \\
\hline $\begin{array}{l}\text { Strains of Bacillus } \\
\text { sphaericus group }\end{array}$ & rhombohedral calcite, hexagonal vaterite & & Hammes et al. [33] \\
\hline
\end{tabular}



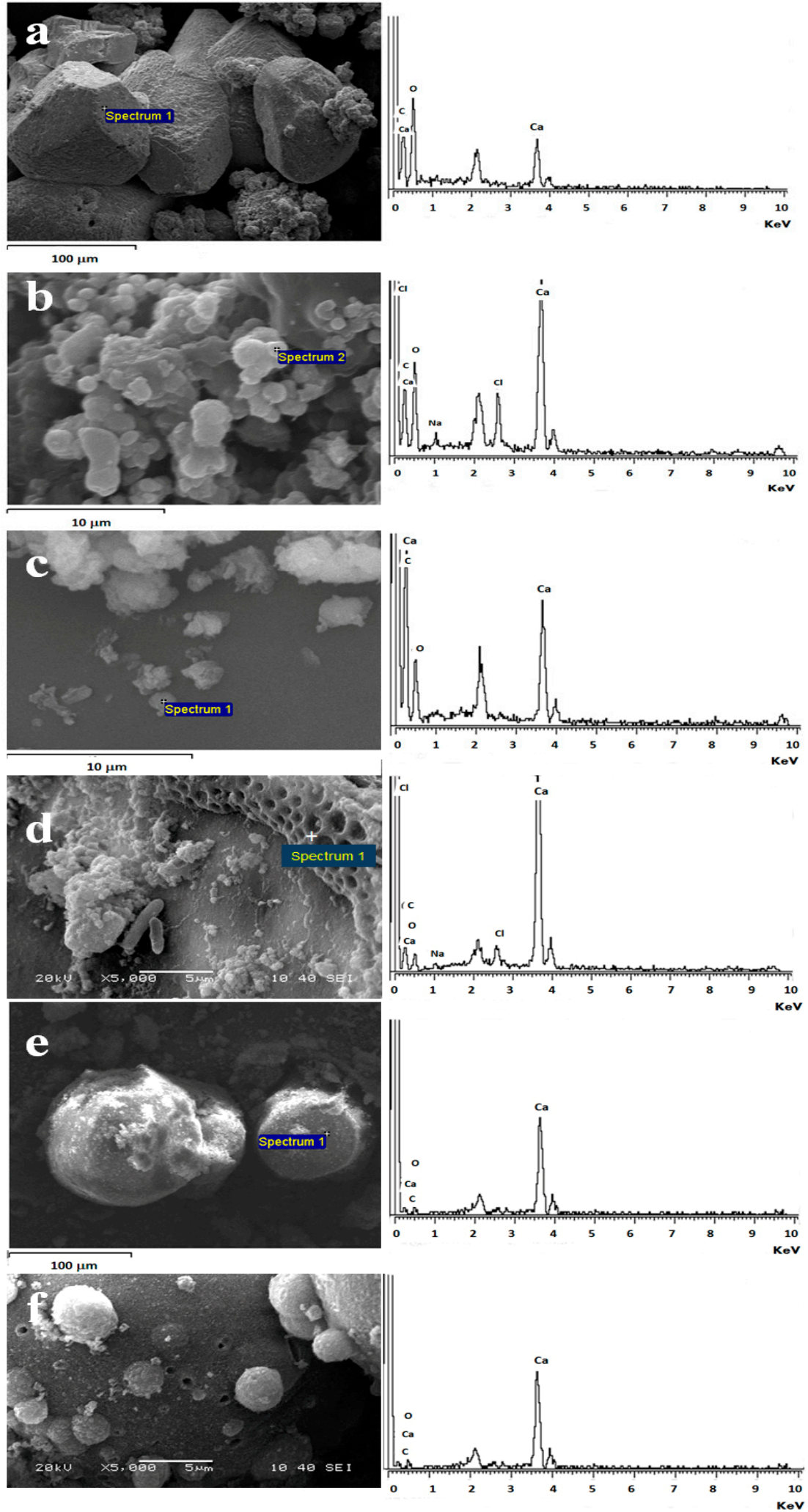

Figure 1. Scanning electron microscopy with energy dispersive X-ray (SEM-EDX) analysis of calcium carbonate crystals produced by various bacterial ureolytic species in aqueous solution supplemented with $\mathrm{Ca}^{2+}$. Crystals produced by B. subtilis LN8B (a), Halomonas sp. LM12ABN (b), Rhodococcus erythropolis TN24F (c), Bacillus subtilis TN21G (d), Salinivibrio sp. LM9A (e) and Bacillus subtilis LN13DC (f). Methodology can be reviewed in [43]. 
The use of ions present in seawater for crystal formation mediated by ureolytic bacteria, specifically Bacillus sp. DSM23526 strain MCP-11 [60] was first described by Cheng et al. [57]. Bacillus sp. induced calcite crystals formation, additionally the presence of magnesium carbonate trihydrate $\left(\mathrm{MgCO}_{3} \cdot 3 \mathrm{H}_{2} \mathrm{O}\right)$ was detected, which is a consequence of the high concentration of magnesium ion in seawater (above $50 \mathrm{mM}$ ), which is five times more than the calcium concentration (10 $\mathrm{mM})$ [57].

From calcite precipitation induced by ureolytic bacteria, some authors have evaluated to add divalent metals (e.g., $\mathrm{Pb}, \mathrm{Zn}, \mathrm{Ba}$ and $\mathrm{Cd}$ ) and radionuclides (e.g., ${ }^{90} \mathrm{Sr}$ and ${ }^{60} \mathrm{Co}$ ) [61] in a coprecipitation of the contaminants in the original calcite precipitates, which would occur by the isomorphic replacement of the $\mathrm{Ca}^{2+}$ in the lattice structure and the incorporation in the interstitial positions or at defect vacancies $[62,63]$ generating an important application for biomineralization as a remediation strategy for contaminated groundwater [63].

\section{Application of Ureolytic Bacteria for the Removal of Heavy Metals and Radionuclides from Aqueous Solutions}

The increase in industrial activity has resulted in the accumulation of a number of pollutants such as heavy metals and radionuclides that cause problems both to the environment and to human health. These come from industrial effluents, mining activities, waste from the use of fertilizers and pesticides in agriculture, burning of waste and fossil fuels, and leaching of dumps [47]. Urban solid waste dumps are the common method for the organized disposal of waste in the world and the produced leachate contains a wide variety of organic and inorganic pollutants that occasionally can reach groundwater.

The most important pollutants include metals such as $\mathrm{Cu}, \mathrm{Cr}, \mathrm{Cd}, \mathrm{Hg}, \mathrm{Sb}, \mathrm{Pb}, \mathrm{As}, \mathrm{Co}, \mathrm{Zn}$ and $\mathrm{Sn}$, and radionuclides such as $\mathrm{U}, \mathrm{Th}, \mathrm{Am}, \mathrm{Ra}$ and $\mathrm{Sr}$ [38]. The latter is one of the most studied through the use of ureolytic bacteria, which comes from various sources such as plastics, concrete, plasters or other manufactured products [64]. The danger with heavy metals and radionuclides is that they are not chemically or biologically degradable and once used and/or released, they can remain in the environment for hundreds of years, and their concentration in living beings increases as they are ingested by the members of the food chain [65].

Regarding heavy metals, there are several conventional techniques for their elimination including chemical precipitation, oxidation/reduction, filtration, ion exchange, reverse osmosis, membrane technology, evaporation method and electrochemical treatment. However, these traditional methods often are ineffective, expensive, consume energy and high quantities of chemicals [6]. When the concentration of the heavy metals is less than $100 \mathrm{mg} / \mathrm{L}$, these technologies become inefficient leading to the use of bioremediation technologies $[6,66]$.

One of the most used bioremediation technologies in the removal of heavy metals mainly from soils is phytoremediation. However, it has some limitations due to reliance on plant growth conditions such as climate, geology, altitude and temperature [58].

Alternatively, there are other soil and water remediation technologies based on the use of microorganisms mediated by different bioremediation mechanisms, including biosorption, metal-microbe interactions, bioaccumulation, biotransformation, bioleaching and finally, biomineralization [66].

So far, the most described biomineralization technology is mediated by the action of ureolytic microorganisms. One of the advantages of using this type of microorganism for bioremediation of metals from soil or water is its ability to efficiently immobilize these toxic metals by precipitation or coprecipitation with $\mathrm{CaCO}_{3}$, dependent of metal valence status and redox potential [38]. In addition, its high stability and the coprecipitation potential of radionuclides or heavy metals is an attractive application of the ureolytic bacteria use [6].

Ammonium ions can exchange heavy metal ions and other ions like calcium on grain surfaces in subsurface environment, and this in turn increases the bioavailability of these heavy metals [67]. On the other hand, the carbonate ions promote the precipitation of calcium carbonate and coprecipitation of heavy metals in high $\mathrm{pH}$ environments [68,69]. Although most of the studies are related to 
the bioremediation of contaminated soils, they begin with tests on aqueous solutions and the immobilization process may enable metal(loid)s to be transformed in situ into insoluble and chemically inert forms and are applicable to removing metals from aqueous solution. For example, Achal et al. [70] describe the ability of Kocuria flava CR1 to remove $\mathrm{Cu}$ from the environment at concentrations of $100 \mathrm{mg} / \mathrm{L}$. In the presence of urea, K. flava is able to remove $95 \%$ of copper in $120 \mathrm{~h}$, without urea it removes only $68 \%$ evidencing the ureolytic character of the metabolism used by the bacterium; this is corroborated with an optimum $\mathrm{pH}$ of 8 for a complete removal of copper. Another study by Achal et al. [58] assesses tolerance to As(III) of Sporosarcina ginsengisoli CR5 isolated from a site contaminated with As in Urumqi, China. Bioassays in the presence of urea and $50 \mathrm{mM}$ of As(III) indicated that this strain is capable of synthesizing ureases for 7 days of a test, with a maximum production of $412 \mathrm{U} / \mathrm{mL}$ at $120 \mathrm{~h}$, remediating $96.3 \%$ of the As present. The introduction of this indigenous bacterium provides a potential bioremediation process to highly metal-contaminated water and soils.

Among the examples, Isik [71] uses ureolytic bacteria as nickel adsorbents by comparing a living and nonliving ureolytic mixed culture (UMC) to remove $\mathrm{Ni}^{2+}$ from synthetic wastewater solutions, demonstrating a greater efficiency in the living culture dependent on ureolytic metabolism. For chromium, a study by Altaş et al. [72] determined the potential as sorbent for $\mathrm{Cr}^{6+}$ from an aqueous solution and regarding to $\mathrm{Cu}^{2+}$, Simsek et al. [73] confirmed the ability of UMC for its adsorption by ureolytic bacteria. This last study was carried out under batch conditions, removing $99 \% \mathrm{Cu}^{2+}$ from an initial solution with $100 \mathrm{mg} / \mathrm{L}$ of this metal.

Several studies have also been carried out regarding the removal of radionuclides, particularly Mitchell and Ferris [63] analyzed the coprecipitation of $\mathrm{Sr}^{2+}$, establishing nucleation and growth of calcite precipitates by bacterial ureolysis in artificial groundwater free of $\mathrm{Sr}$ replicating the composition of a contaminated aquifer. It was established that in the presence of $\mathrm{Sr}^{2+}$, the calcite crystals had an average diameter of $<840 \mathrm{~nm}$ as compared, the diameter in the absence of $\mathrm{Sr}^{2+}$ had a gradual size increase of $<1000 \mathrm{~nm}$. The speed of growth of the crystals is limited by the speed of advection of the solute to the surface of the crystal. The crystals generated in the presence of Sr are smaller and, therefore, more soluble. However, it does not significantly reduce the long-term effectiveness of $\mathrm{Sr}$ immobilization, obtaining $99 \%$ of the calcite precipitation and the coprecipitate of $\mathrm{Sr}$.

Another example is described by Achal et al. [59], who determined the precipitation of calcite by ureolysis to remediate the radioactive $\mathrm{Sr}\left({ }^{90} \mathrm{Sr}\right)$ present in the quartz sand of an aquifer using the Halomonas sp. bacterium, resistant to this element. It was determined an $80 \%$ removal of ${ }^{90} \mathrm{Sr}$ from the soluble-exchangeable fraction of the quartz sand of the aquifer. X-ray diffraction detected calcite, vaterite and aragonite along with a solid solution of calcite-strontianite $\left(\mathrm{SrCO}_{3}\right)$ in a bioremediated sample indicating that Sr was incorporated into calcite. This demonstrates that through biomineralization, the soluble $\mathrm{Sr}$ in the form of biomineral is abducted and playing an important role in the bioremediation of $\mathrm{Sr}$ from the ecological and economic point of view. The Sr has also been removed using the Bacillus pasteurii bacterium [69] from synthetic waters whose composition simulates an aquifer from the Snake River plain, Idaho. It was possible to demonstrate the co-precipitation of calcite with Sr by X-ray diffraction and Time-of-flight secondary ion mass spectrometry (ToF SIMS), proving that $\mathrm{Sr}$ was not only absorbed at the surface, but was present in depth within the particles. This is determined by the global rate of calcite precipitation, while the latter indicates a higher absorption of Sr in the solid. Subsequently, Fujita et al. [68] confirmed the presence of the ureC gene in waters and sediments in Sr removal tests in situ with combined calcite precipitation.

\section{Phosphorus Precipitation from Wastewaters}

The high demographic and industrial growth in recent years have led to an increase in water pollution. In particular, nutrient discharges into natural waters have contributed to an increase in eutrophication problems, resulting in serious consequences for aquatic life as well as for the provision of water for industrial and domestic use [74]. In the case of the food industry related to the production 
of frozen vegetables and prefried potatoes, the main problem lies in the presence of large amounts of phosphate in wastewater, leading to its accumulation in the process water unless elimination of phosphate occurs before to be reused [75]. One of the major contaminants due to this process is struvite. Struvite $\left(\mathrm{NH}_{4} \mathrm{MgPO}_{4} \cdot 6 \mathrm{H}_{2} \mathrm{O}\right)$ is the most common form of magnesium phosphate found in nature [76]. Regarding wastewater treatment plants, the areas most affected by struvite deposition are places where there is an increase in turbulence, such as pumps, aerators and pipe curves [77].

Although struvite is a problem in wastewater treatment plants, it also has a potential use as fertilizer [78]. Moreover, other benefits of struvite precipitation include the reduction of phosphorus and nitrogen loading on secondary mud and recycled mud to the top of the list of wastewater treatment works [79]. Phosphorus recovery not only prevents eutrophication but also preserves limited natural resources.

The conventional method to eliminate phosphorus from wastewater is the addition of flocculants such as ferric chloride and aluminum [80]. However, the main problem is the high economic cost of these chemical flocculants, and in many cases, this process can be replaced by the biological crystallization or biomineralization of phosphorus [80]. There are three types of commercial technologies for phosphorus biological disposal, called Phostrip, modified processes of Bardenpho and Rotanox [81].

Several studies have been published that focus on the treatment of wastewater both to prevent eutrophication and to recover phosphorus and its potential use as a fertilizer using the ureolytic metabolism of bacteria. Carballa et al. [78] describe a method to remove phosphate from wastewater from anaerobic effluents by ureolytic precipitation. This study applied phosphate precipitation mediated by ureolytic bacteria when the concentration of this ion in wastewater from a vegetable

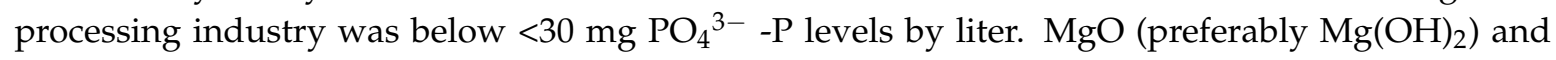
urea were added to facilitate precipitation, decreasing its concentration to approximately $5-7 \mathrm{mg}$ $\mathrm{PO}_{4}{ }^{3-}$-P per liter. A study by Desmidt et al. [75] evaluated the removal of phosphate from industrial anaerobic effluents. They first modeled the precipitation of magnesium ammonium phosphate (MAP) as struvite with MAPLE and PHREEQC programs; however, the obtained experimental results were better than those expected with precipitation models. According to this, they indicated that a $\mathrm{pH}$ above 8.5 and the use of $\mathrm{MgCl}_{2}$ produced better results compared with the use of $\mathrm{MgO}$ for the phosphate precipitation from industrial anaerobic effluent. Subsequently, Desmidt et al. [82] used water from a potato processing company for the comparison of MAP precipitation using ureolytic crystallization combined with an autotrophic nitrogen removal process with NuReSys ${ }^{\circledR}$ technology, which increases $\mathrm{pH}$ by $\mathrm{NaOH}$ and recovers orthophosphate $\left(\mathrm{PO}_{4}-\mathrm{P}\right)$ and ammoniacal nitrogen $\left(\mathrm{NH}_{4}-\mathrm{N}\right)$ to form pure struvite crystals $\left(\mathrm{NH}_{4} \mathrm{MgPO}_{4} \cdot 6 \mathrm{H}_{2} \mathrm{O}\right)$ (http:/ / www.nuresys.be/). The importance of this comparison is to establish that MAP ureolytic crystallization is competitive with NuReSys®technology in terms of operational cost and removal efficiency; however, further research is still needed to obtain more crystals. Desmidt et al. [83] determined that several factors influence struvite precipitation, including calcium concentration, concentration of $\mathrm{PO}_{4}-\mathrm{P}, \mathrm{Mg}^{2+}: \mathrm{PO}_{4}{ }^{3-}$ molar ratio and ionic strength. Despite good results, the fact that the wastewater contains a low concentration of $\mathrm{PO}_{4}-\mathrm{P}$ influences the application of this technology economically since the addition of other chemicals like urea to carry out the process is necessary.

Another application in the recovery of phosphorus $(\mathrm{P})$ by ureolytic bacteria corresponds to its removal from urine using seawater. Dai et al. [84] determined that $98 \%$ of $\mathrm{P}$ from urine can be precipitated in the presence of seawater, in only 10 minutes when $40-75 \%$ of the urea present in the urine is hydrolyzed, while magnesium and ammonium phosphate (MAP) was the predominant component of the precipitates found. However, in this study they do not mention ureolytic bacteria unlike Tang et al. [85], who describe the Seawater-based Urine Phosphorus Recovery (SUPR) system indicating that native urine and/or seawater bacteria provide a ureolytic population in situ facilitating phosphate precipitation in SUPR. 


\section{Precipitation of Ions from Wastewater and Seawater}

Calcium present in wastewater and seawater generates several operational problems-mainly scaling in pipelines and reactors due to its precipitation as sulphate, phosphate and/or carbonate salt [86]. Regarding seawater, this has a typical salinity of $35 \mathrm{~g} / \mathrm{kg}$ of solution and the $\mathrm{NaCl}$ concentration around 0.5-0.6 M. In addition to this salt, seawater contains a number of important secondary ions. Most cations such as calcium, magnesium and strontium are free; however, there is a tendency to form ionic pairs with sulphate [87]. To remove calcium, there are chemical crystallization reactors based on the addition of a base $\left(\mathrm{NaOH}\right.$ or $\left.\mathrm{Ca}(\mathrm{OH})_{2}\right)$ in the presence of nucleation sites for the precipitation of crystals; however, most of the time these are expensive, complex and sometimes generate highly alkaline effluents due to the reagents used.

For example, in the mining industry, the seawater is used without desalination, affecting mineral flotation of copper-molybdenum due to the presence of high concentrations of secondary ions, such as $\mathrm{Mg}^{2+}$ and $\mathrm{Ca}^{2+}$, which generate a buffer effect $[86,88]$ and increases the consumption of reagents used to modify the $\mathrm{pH}$ in the solution. In the case of adding lime or another alkalizing agent, colloidal precipitates of these ions are produced which prevent the recovery of some relevant species such as molybdenite $\left(\mathrm{MoS}_{2}\right)$ [88-91]. In addition, the $\mathrm{Cl}^{-}$ion can react with the $\mathrm{Fe}^{2+}$ ions present to create $\mathrm{FeCl}_{2}$. This compound reacts with the dissolved oxygen producing $\mathrm{Fe}_{2} \mathrm{O}_{3}$ and $\mathrm{FeCl}_{3}$, which are considered strong oxidizing agents of pipes and/or equipment [91]. Another mineral originated through this mechanism is calcium carbonate $\left(\mathrm{CaCO}_{3}\right)$, the most common sedimentary mineral present on Earth [30].

The application of biomineralization processes mediated by ureolytic bacteria for calcium removal and other ions from seawater and wastewater is poorly described.

One of the earliest studies is by Hammes et al. [33], which looked at the removal of calcium by biomineralization from industrial wastewater $\left(\mathrm{Ca}^{2+} 500-1500 \mathrm{mg} / \mathrm{L}\right)$ through the use of a semicontinuous reactor (BCR), removing about $90 \%$ of calcium in the period under test. The water came from a paper recycling facility. Although they do not specifically detail the type of microorganisms used, they attribute calcium precipitation to ureolytic metabolism. They also suggest that the chemical precipitation of calcium carbonate is controlled by four factors: i) calcium ion concentration; ii) carbonate concentration; iii) $\mathrm{pH}$ and, iv) presence of nucleation sites. In the microbial precipitation of calcium carbonate, the first three factors are key, while the fourth is replaced by the presence of bacteria as they act as nucleation sites themselves. Then Işik et al. [42] determined the effect of urea concentration on the $\mathrm{BCR}$ reactor yield in terms of the removal of organic matter over time and, secondly, evaluated the ammonia toxicity in the ureolytic mixed culture of S. pasteurii confirming that this bacterium isolated from alkaline environments ( $\mathrm{pH}$ values of 9-13) can induce the calcite biomineralization. Furthermore, this bacterium is widely used in controlled laboratory conditions and in the presence of industrial solid waste such as cement kiln dust (CKD) and lime kiln dust (LKD). Its potential for grain consolidation for a type of CKD mixed with granulated blast furnace slag (GGBS), has potential application in bioclogging and biocementation. The results demonstrate the formation of stable biocalcite in the presence of CKD, with a yield that depends on the $\mathrm{pH}$ value and the content of free calcium ions, the benefits of this technology in construction costs and reduction of environmental contamination are promising [92].

In a study developed by Uad et al. [50], the biomineralization of calcium carbonate was carried out by bacteria of the Bacillus and Virgibacillus genus isolated from saline environments and cultivated in seawater and brines from desalination plants, confirming that these species are able to precipitate calcium carbonate when grown in culture media supplemented with organic matter.

Regarding magnesium, most publications on its precipitation indicate that they are part of struvite crystals and are related to the recovery of phosphates from wastewater through chemical crystallization [93]. However, there are also records that biologically mediated struvite precipitation is possible [94]. Various bacteria isolated from waters and soils such as Myxococcus sp., Arthrobacter sp. and Pseudomonas sp. have been described as capable of precipitating struvite under laboratory 
conditions [94]. Among them, Myxococcus xanthus biomineralizes struvite [95] and on the other hand, Halorubrum distributum, Halobacterium salinarium and Brevibacterium antiquum have also been reported as forming magnesium phosphate crystals [96]. However, precipitation of magnesium from seawater using ureolytic bacteria has been poorly described and is related to what has already been described for the precipitation of struvite from wastewaters. Nevertheless, Arias et al. [43] determined that ureolytic bacteria isolated from the Atacama Desert act as biomineralizers of calcium and magnesium ions present in seawater; this could be used as a potential pretreatment technology to seawater or as a selective biodesalation. In this case Rhodococcus erythropolis precipitates to $\sim 95 \%$ soluble calcium and $8 \%$ magnesium. The analysis of crystals showed that the components correspond to $\sim 12.69 \%$ monohydrocalcite, $\sim 30.72 \%$ struvite and $\sim 56.59 \%$ halite, concluding that these results have great potential for their application as a pretreatment to improve water quality for industrial processes.

\section{Current Limitations for the Application of Biomineralization}

Biomineralization as technology has many interesting applications that could solve many problems without a high economic or environmental cost; however, it is necessary to solve some limitations to reach a commercial scale. Firstly, a complete life cycle analysis of the biomineralization technology should be carried out. In the case of using ureolytic bacteria, as byproducts of the metabolism, ammonium and nitrate are produced, which could be toxic and harmful to human health in high concentration [6,97]. Secondly, microbial metabolic processes are generally slower and more complex than chemical processes; consequently, it is necessary to optimize all factors involved, such as temperature, $\mathrm{pH}$, urea concentration, salts present, considering without doubt the bacterial species to use and the necessary conditions to favor its metabolism. Thirdly, the implementation of technologies based on biomineralization for water treatment requires the expertise of many disciplines including the efforts of engineers, microbiologists, biochemists, among others. Finally, it is necessary to consider the economic limitations, especially in the replacement of reagents and nutrients of analytical grade used in most studies by others of lower cost. Additionally, although some studies, such as those by Hammes et al. [33] and IŞik et al. [41], use a semicontinuous reactor, there are no other described technologies that allow for further thought in regards to scale thus far.

\section{Conclusions}

Biomineralization or MICP provides the basis for numerous technologies that allow for the removal of ions from different types of water including freshwater, wastewater and seawater, which would allow for the discharge and/or a harmless use of these waters. Numerous studies have employed the use of microorganisms whose ureolytic metabolism facilitates the formation of various types of biominerals, with calcite formation the most common. The various applications of ureolytic metabolism include the removal of heavy metals and radionuclides-such as $\mathrm{Cu}, \mathrm{As}, \mathrm{Ni}, \mathrm{Cr}$ and $\mathrm{Sr}$, among others-through calcite coprecipitation demonstrating the great potential of this technology in incorporating these elements into low-solubility biominerals that are stable over time and inert compared to phytoremediation technologies. In addition to the above, MICP also facilitates the removal of specific ions from wastewater and seawater, including phosphorus, magnesium and calcium. Even though the MICP process has many merits, further study is needed to overcome the limitations to use this technology prior to its commercialization.

Acknowledgments: This publication was supported by Anillo Programme-Grant $\mathrm{n}^{\circ}$ ACT1201-Atacama Seawater, PhD Scholarship CONICYT $n^{\circ}$ 21130712, CICITEM Project $n^{\circ}$ R10C1004 and the Regional Government of Antofagasta.

Author Contributions: DA, LC, and MR contributed equally to the writing of this review.

Conflicts of Interest: The authors declare no conflicts of interest. 


\section{References}

1. Anaya, M.; Martínez, J.M. Manual de Captación de Agua de Lluvia Para Áreas Rurales: Sistemas de Captación Y Aprovechamiento del Agua de Lluvia Para Uso Doméstico y Consumo Humano en América Latina y el Caribe. México, Instituto de Enseñanza e Investigación en Ciencias Agrícolas. 2007. Available online: http:/ / www.pnuma.org/recnat/esp/public.php (accessed on 15 April 2016).

2. Lattemann, S.; Höpner, T. Environmental Impact and Impact Assessment of Seawater Desalination. Desalination 2008, 220, 1-15. [CrossRef]

3. Dawoud, M.A.; Al Mulla, M.M. Environmental Impacts of Seawater Desalination: Arabian Gulf Case Study. Int. J. Environ. Sustain. 2012, 1, 22-37. [CrossRef]

4. DeJong, J.T.; Soga, K.; Banwart, S.; Whalley, W.R.; Ginn, T.R.; Nelson, D.C.; Mortensen, B.M.; Martinez, B.C.; Barkouki, T. Soil Engineering In Vivo: Harnessing Natural Biogeochemical Systems for Sustainable, Multi-functional Engineering Solutions. J. R. Soc. Interface 2011, 8, 1-15. [CrossRef] [PubMed]

5. Sarikaya, M. Biomimetics: Materials Fabrication through Biology. Proc. Natl. Acad. Sci. USA 1999, 96, 14183-14185. [CrossRef] [PubMed]

6. Anbu, P.; Kang, C.H.; Shin, Y.-J.; So, J.-S. Formations of Calcium Carbonate Minerals by Bacteria and its Multiple Applications. SpringerPlus 2016, 5, 250. [CrossRef] [PubMed]

7. Benzerara, K.; Miot, J.; Morin, G.; Ona-Nguema, G.; Skouri-Panet, F.; Férard, C. Significance, Mechanisms and Environmental Implications of Microbial Biomineralization. C. R. Geosci. 2011, 343, 160-167. [CrossRef]

8. Phillips, A.J.; Gerlach, R.; Lauchnor, E.; Mitchell, A.C.; Cunningham, A.B.; Spangler, L. Engineered Applications of Ureolytic Biomineralization: A Review. Biofouling 2013, 29, 715-733. [CrossRef] [PubMed]

9. Jimenez-Lopez, C.; Jroundi, F.; Rodriguez-Gallego, M.; Arias, J.M.; González-Muñoz, M.T. Biomineralization induced by Myxobacteria. Commun. Curr. Res. Educ. Top. Trends Appl. Microbiol. 2007, 1, 143-154.

10. Sarayu, K.; Iyer, N.G.; Ramachandra-Murty, A. Exploration on the Biotechnological Aspect of the Ureolytic Bacteria for the Production of the Cementitious Materials-A Review. Appl. Biochem. Biotechnol. 2014, 172, 2308-2323. [CrossRef] [PubMed]

11. Stocks-Fischer, S.; Galinat, J.K.; Bang, S.S. Microbiological Precipitation of $\mathrm{CaCO}_{3}$. Soil Biol. Biochem. 1999, 31 , 1563-1571. [CrossRef]

12. Chafetz, H.S.; Buczynski, C. Bacterially Induced Lithification of Microbial Mats. Palaios 1992, 7, $277-293$. [CrossRef]

13. Ben Omar, N.; Martínez-Cañamero, M.; González-Muñoz, M.T.; Arias, J.M.; Huertas, F. Struvite Crystallization on Myxococcus cells. Chemosphere 1995, 30, 2387-2396. [CrossRef]

14. Von Knorre, H.; Krumbein, W.E. Microbial Sediments; Riding, R., Awaramik, S., Eds.; Springer: Berlin, Germany, 2000; pp. 25-31.

15. Paerl, H.W.; Stepp, T.F.; Reid, R.P. Bacterially Mediated Precipitation in Marine Stromatolites. Environ. Microbiol. 2001, 3, 123-130. [CrossRef] [PubMed]

16. Decho, A.W. Microbial Biofilms in Intertidal Systems: An Overview. Cont. Shelf. Res. 2000, 20, 1257-1273. [CrossRef]

17. Pentecost, A. Association of Cyanobacteria with Tufa Deposits: Identity, Enumeration and Nature of the Sheath Material Revealed by Histochemistry. Geomicrobiol. J. 1985, 4, 285-298. [CrossRef]

18. Whiffin, V.S.; Van Paassen, L.A.; Harkes, M.P. Microbial Carbonate Precipitation as a Soil Improvement Technique. Geomicrobiol. J. 2007, 24, 417-423. [CrossRef]

19. Wright, D.T. The Role of Sulphate-Reducing Bacteria and Cyanobacteria in Dolomite Formation in Distal Ephemeral Lakes of the Coorong region, South Australia. Sediment. Geol. 1999, 126, 147-157. [CrossRef]

20. Castanier, S.; Le Métayer-Levrel, G.; Orial, G.; Loubière, J.-F.; Pethuisot, J.P. Of Microbes and Art: The Role of Microbial Communities in the Degradation and Protection of Cultural Heritage; Ciferri, O., Ed.; Plenun: New York, NY, USA, 2000; pp. 203-218.

21. Ben Chekroun, K.; Rodriguez-Navarro, C.; Gonzalez-Muñoz, M.T.; Arias, J.M.; Cultrone, G.; Rodriguez-Gallego, M. Precipitation and Growth Morphology of Calcium Carbonate induced by Myxococcus xanthus: Implications for Regognition of Bacterial Carbonates. J. Sediment. Res. 2004, 74, 868-876. [CrossRef]

22. Rivadeneyra, M.A.; Párraga, J.; Delgado, R.; Ramos-Cormenzana, A.; Delgado, G. Biomineralization of Carbonates by Halobacillus trueperi in Solid and Liquid Media with Different Salinities. FEMS Microbiol. Ecol. 2004, 48, 39-46. [CrossRef] [PubMed] 
23. Baskar, S.; Baskar, R.; Mauclaire, L.; McKenzie, J.A. Microbially induced Calcite Precipitation by Culture Experiments-Possible Origin for Stalactites in Sahastradhara, Dehradun, India. Curr. Sci. 2006, 90, 58-64.

24. Coates, J.D.; Anderson, R.T.; Woodward, J.C.; Phillips, E.J.P.; Lovley, D.R. Anaerobic Hydrocarbon Degradation in Petroleum-Contaminated Harbor Sediment Under Sulfate-Reducing and Artificially Imposed Iron-Reducing Conditions. Environ. Sci. Technol. 1996, 30, 2784-2789. [CrossRef]

25. Ringelberg, D.B.; White, D.C.; Nishijima, M.; Sano, H.; Burghardt, J.; Stackebrandt, E.; Nealson, K.H. Polyphasic taxonomy of the genus Shewanella and description of Shewanella oneidensis sp. nov. Int. J. Syst. Bacteriol. 1999, 49, 705-724.

26. Jerden, J.L.; Sinha, A.K. Phosphate Based Immobilization of Uranium in an Oxidizing Bedrock Aquifer. Appl. Geochem. 2003, 18, 823-843. [CrossRef]

27. Jroundi, F.; Merroun, M.; Arias, J.M.; Rossberg, A.; Selenska-Pobell, S.; Gonzalez-Muñoz, M.T. Spectroscopic and Microscopic Characterization of Uranium Biomineralization by Myxococcus xanthus. Geomicrobiol. J. 2007, 24, 441-449. [CrossRef]

28. Takazoe, I.; Vogel, J.; Ennever, J. Calcium Hydroxyapatite Nucleation by Lipid Extract of Bacterionema matruchotii. J. Dent. Res. 1970, 49, 395-398. [CrossRef] [PubMed]

29. Smith, W.; Streckfu, J.; Vogel, J.; Ennever, J. Struvite Crystals in Colonies of Bacterionema matruchotii and its Variants. J. Dent. Res. 1971, 50, 777-781. [CrossRef] [PubMed]

30. Al-Thawadi, S.M. Ureolytic Bacteria and Calcium Carbonate Formation as a Mechanism of Strength Enhancement of Sand. J. Adv. Sci. Eng. Res. 2011, 1, 98-114.

31. Abo-El-Enein, S.A.; Ali, A.H.; Talkhan, F.N.; Abdel-Gawwad, H.A. Utilization of Microbial Induced Calcite Precipitation for Sand Consolidation and Mortar Crack Remediation. HBRC J. 2012, 8, 185-192. [CrossRef]

32. Bosak, T. Calcite Precipitation, Microbially Induced. In Encyclopedia of Earth Sciences Series; Reitner, J., Thiel, V., Eds.; Springer: Dordrecht, The Netherlands, 2012; pp. 223-227.

33. Hammes, F.; Seka, A.; De Knijf, S.; Verstraete, W. A Novel Approach to Calcium Removal from Calcium-Rich Industrial Wastewater. Water Res. 2003, 37, 699-704. [CrossRef]

34. Burbank, M.B.; Weaver, T.J.; Williams, B.C.; Crawford, R.L. Urease Activity of Ureolytic Bacteria Isolated from Six Soils in which Calcite was Precipitated by Indigenous Bacteria. Geomicrobiol. J. 2012, 29, 389-395. [CrossRef]

35. Yoon, J.H.; Lee, K.C.; Weiss, N.; Kho, Y.H.; Kang, K.H.; Park, Y.H. Sporosarcina aquimarina sp. nov., a Bacterium Isolated from Seawater in Korea, and transfer of Bacillus globisporus (Larkin and Stokes 1967), Bacillus psychrophilus (Nakamura 1984) and Bacillus pasteurii (Chester 1898) to the genus Sporosarcina as Sporosarcina globispora comb. nov., Sporosarcina psychrophila comb. nov. and Sporosarcina pasteurii comb. nov., and Emended Description of the Genus Sporosarcina. Int. J. Syst. Evol. Microbiol. 2001, 51, 1079-1086. [PubMed]

36. Krajewska, B. Ureases I. Functional, Catalytic and Kinetic Properties: A Review. J. Mol. Catal. B Enzym. 2009, 59, 9-21. [CrossRef]

37. Knoll, A.H. Biomineralization and Evolutionary History. Rev. Mineral. Geochem. 2003, 54, 329-356. [CrossRef]

38. Kumari, D.; Qian, X.Y.; Pan, X.; Achal, V.; Li, Q.; Gadd, G.M. Microbially-induced Carbonate Precipitation for Immobilization of Toxic Metals. Adv. Appl. Microbiol. 2016, 94, 79-108. [PubMed]

39. Ehrlich, L.; Newman, D.K. Geomicrobiology, 5th ed.; CRC Press; Taylor \& Francis Group: New York, NY, USA, 2009.

40. Dhami, N.K.; Reddy, M.S.; Mukherjee, A. Biomineralization of Calcium Carbonates and their Engineered Applications: A Review. Front. Microbiol. 2013, 4, 314. [CrossRef] [PubMed]

41. IŞık, M.; AltaŞ, L.; KurmaÇ, Y.; Özcan, S.; OruÇ, Ö. Effect of Hydraulic Retention Time on Continuous Biocatalytic Calcification Reactor. J. Hazard. Mater. 2010, 182, 503-506. [CrossRef] [PubMed]

42. Işik, M.; Altaş, L.; Özcan, S.; Şimşek, I.; Aĝgdaĝ, O.N.; Alaş, A. Effect of Urea Concentration on Microbial Ca Precipitation. J. Ind. Eng. Chem. 2012, 18, 1908-1911. [CrossRef]

43. Arias, D.; Cisternas, L.A.; Rivas, M. Biomineralization of Calcium and Magnesium Crystals from Seawater by Halotolerant Bacteria Isolated from Atacama Salar (Chile). Desalination 2017, 405, 1-9. [CrossRef]

44. Dick, J.; De Windt, W.; De Graef, B.; Saveyn, H.; Van der Meeren, P.; De Belie, N.; Verstraete, W. Bio-deposition of a Calcium Carbonate Layer on Degraded Limestone by Bacillus species. Biodegradation 2006, 17, 357-367. [CrossRef] [PubMed] 
45. Silva-Castro, G.A.; Uad, I.; Gonzalez-Martinez, A.; Rivadeneyra, A.; Gonzalez-Lopez, J.; Rivadeneyra, M.A. Bioprecipitation of Calcium Carbonate Crystals by Bacteria Isolated from Saline Environments Grown in Culture Media Amended with Seawater and Real Brine. BioMed Res. Int. 2015, 2015, 816102. [CrossRef] [PubMed]

46. Achal, V.; Mukherjee, A.; Kumari, D.; Zhang, Q. Biomineralization for Sustainable Construction-A review of Processes and Applications. Earth-Sci. Rev. 2015, 148, 1-17. [CrossRef]

47. Li, M.; Cheng, X.; Guo, H. Heavy Metal Removal by Biomineralization of Urease Producing Bacteria Isolated from Soil. Int. Biodeterior. Biodegrad. 2012, 76, 81-85. [CrossRef]

48. Barabesi, C.; Galizzi, A.; Mastromei, G.; Rossi, M.; Tamburini, E.; Perito, B. Bacillus subtilis Gene Cluster Involved in Calcium Carbonate Biomineralization. J. Bacterial. 2007, 189, 228-235. [CrossRef] [PubMed]

49. Achal, V.; Mukherjee, A.; Basu, P.C.; Reddy, M.S. Strain Improvement of Sporosarcina pasteurii for Enhanced Urease and Calcite Production. J. Ind. Microbial. Biotechnol. 2009, 36, 981-988. [CrossRef] [PubMed]

50. Uad, I.; Gonzalez-Lopez, J.; Silva-Castro, G.A.; Vílchez, J.I.; Gonzalez-Martinez, A.; Martin-Ramos, D.; Rivadeneyra, M.A. Precipitation of Carbonates Crystals by Bacteria Isolated from a Submerged fixed-film Bioreactor used for the Treatment of urban Wastewater. Int. J. Environ. Res. 2014, 8, 435-446.

51. Mitchell, A.C.; Ferris, F.G. The Influence of Bacillus pasteurii on the Nucleation and Growth of Calcium Carbonate. Geomicrobiol. J. 2006, 23, 213-226. [CrossRef]

52. Rodriguez-Navarro, C.; Jimenez-Lopez, C.; Rodriguez-Navarro, A.; Gonzalez-Muñoz, M.T.; Rodriguez-Gallego, M. Bacterially mediated Mineralization of Vaterite. Geochim Cosmochim. Acta 2007, 71, 1197-1213. [CrossRef]

53. Morse, J.W.; Casey, W.H. Ostwald Processes and Mineral Paragenesis in Sediments. Am. J. Sci. 1988, 288, 537-560. [CrossRef]

54. Zamarreño, D.; Inkpen, R.; May, E. Carbonate Crystals precipitated by Freshwater Bacteria and their use as a Limestone Consolidant. Appl. Environ. Microbiol. 2009, 75, 5981-5990. [CrossRef] [PubMed]

55. Mitchell, A.C.; Phillips, A.J.; Schultz, L.; Parks, S.; Spangler, L.; Cunningham, A.; Gerlach, R. Microbial $\mathrm{CaCO}_{3}$ Mineral Formation and Stability in an Experimentally Simulated High Pressure Saline Aquifer with Supercritical $\mathrm{CO}_{2}$. Int. J. Greenh. Gas Control 2013, 15, 86-96. [CrossRef]

56. Kang, C.-H.; Kwon, Y.-J.; So, J.-S. Bioremediation of heavy metals by using bacterial mixtures. Ecol. Eng. 2016, 89, 64-69. [CrossRef]

57. Cheng, L.; Ha Hin, M.A.S.; Cord-Ruwisch, R. Bio-cementation of Sandy Soil using Microbially induced Carbonate Precipitation for Marine Environments. Géotechnique 2014, 64, 1010-1013. [CrossRef]

58. Achal, V.; Pan, X.; Fu, Q.; Zhang, D. Biomineralization Based Remediation of As (III) Contaminated Soil by Sporosarcina ginsengisoli. J. Hazard. Mater. 2012, 201, 178-184. [CrossRef] [PubMed]

59. Achal, V.; Pan, X.; Zhang, D. Bioremediation of Strontium (Sr) Contaminated Aquifer Quartz Sand based on Carbonate Precipitation induced by Sr Resistant Halomonas sp. Chemosphere 2012, 89, 764-768. [CrossRef] [PubMed]

60. Al-Thawadi, S.M.; Cord-Ruwisch, R.; Bououdina, M. Consolidation of Sand Particles by Nanoparticles of Calcite after Concentrating Ureolytic Bacteria in situ. Int. J. Green Nanotechnol. 2012, 4, 1-9. [CrossRef]

61. Knobel, L.L.; Bartholomay, R.C.; Cecil, L.D.; Tucker, B.J.; Wegner, S.J. Chemical Constituents in the Dissolved and Suspended Fractions of Groundwater from Selected Sites, Idaho National Engineering Laboratory and Vicinity, Idaho, 1989; Open-File Report Geological Survey: Idaho Falls, ID, USA, 1992.

62. Reeder, J.R.; Lamble, G.M.; Northrup, P.A. XAFS Study of the coordination and Local Relaxation around $\mathrm{Co}^{2+}, \mathrm{Zn}^{2+}, \mathrm{Pb}^{2+}$ and $\mathrm{Ba}^{2+}$ trace elements in Calcite. Am. Mineral. 1999, 84, 1049-1060. [CrossRef]

63. Mitchell, A.C.; Ferris, F.G. The Coprecipitation of Sr into Calcite precipitates induced by bacterial Ureolysis in Artificial Groundwater: Temperature and Kinetic Dependence. Geochim. Cosmochim. Acta 2005, 69, 4199-4210. [CrossRef]

64. Nigro, A.; Sappa, G.; Barbieri, M. Strontium Isotope as Tracers of Groundwater Contamination. Procedia Earth Planet. Sci. 2017, 17, 352-355. [CrossRef]

65. He, J.; Chen, J.P. A Comprehensive Review on Biosorption of Heavy Metals by Algal Biomass: Materials, Performances, Chemistry, and Modelling Simulation Tools. Bioresour. Technol. 2014, 160, 67-78. [CrossRef] [PubMed] 
66. Dixit, R.; Malaviya, D.; Pandiyan, K.; Singh, U.B.; Sahu, A.; Shukla, R.; Paul, D. Bioremediation of Heavy Metals from Soil and Aquatic Environment: an Overview of Principles and Criteria of Fundamental Processes. Sustainability 2015, 7, 2189-2212. [CrossRef]

67. Wu, Y.J.; Ajo-Franklin, J.B.; Spycher, N.; Hubbard, S.; Zhang, G.; Williams, K.; Taylor, J.; Fujita, Y.; Smith, R. Geophysical Monitoring and Reactive Transport Modeling of Ureolytically driven Calcium Carbonate Precipitation. Geochem. Trans. 2011, 12, 7. [CrossRef] [PubMed]

68. Fujita, Y.; Taylor, J.L.; Wendt, L.M.; Reed, D.W.; Smith, R.W. Evaluating the Potential of Native Ureolytic Microbes to Remediate a ${ }^{90} \mathrm{Sr}$ contaminated Environment. Environ. Sci. Technol. 2010, 44, 7652-7658. [CrossRef] [PubMed]

69. Fujita, Y.; Redden, G.D.; Ingram, J.C.; Cortez, M.M.; Ferris, F.G.; Smith, R.W. Strontium Incorporation into Calcite Generated by Bacterial Ureolysis. Geochim. Cosmochim. Acta 2004, 68, 3261-3270. [CrossRef]

70. Achal, V.; Pan, X.; Zhang, D. Remediation of Copper-Contaminated Soil by Kocuria flava CR1, based on Microbially induced Calcite Precipitation. Ecol. Eng. 2011, 37, 1601-1605. [CrossRef]

71. IŞik, M. Biosorption of Ni(II) from Aqueous Solutions by Living and Non-living Ureolytic Mixed Culture. Colloids Surf. B Biointerfaces 2008, 62, 97-104. [CrossRef] [PubMed]

72. Altaş, L.; Kiliç, A.; Koçyiĝit, H.; Işik, M. Adsorption of Cr(VI) on Ureolytic Mixed culture from Biocatalytic Calcification Reactor. Colloids Surf. B Biointerfaces 2011, 86, 404-408. [CrossRef] [PubMed]

73. Simsek, I.; Karatas, M.; Basturk, E. Cu(II) Removal from Aqueous Solution by Ureolytic mixed Culture (UMC). Colloids Surf. B Biointerfaces 2013, 102, 479-483. [CrossRef] [PubMed]

74. Pastor, L.; Mangin, D.; Barat, R.; Seco, A. A Pilot-scale Study of Struvite Precipitation in a Stirred Tank Reactor: Conditions Influencing the Process. Bioresour. Technol. 2008, 99, 6285-6291. [CrossRef] [PubMed]

75. Desmidt, E.; Verstraete, W.; Dick, J.; Meesschaert, B.D.; Carballa, M. Ureolytic Phosphate Precipitation from Anaerobic Effluents. Water Sci. Technol. 2009, 59, 1983-1988. [CrossRef] [PubMed]

76. Rivadeneyra, M.A.; Pérez-García, I.; Ramos-Cormenzana, A. Influence of Ammonium Ion on bacterial Struvite Production. Geomicrobiol. J. 1992, 10, 125-137. [CrossRef]

77. Stratful, I.; Scrimshaw, M.D.; Lester, J.N. Conditions Influencing the Precipitation of Magnesium Ammonium Phosphate. Water Res. 2001, 35, 4191-4199. [CrossRef]

78. Carballa, M.; Moerman, W.; De Windt, W.; Grootaerd, H.; Verstraete, W. Strategies to Optimize Phosphate Removal from Industrial Anaerobic Effluents by Magnesium Ammonium Phosphate (MAP) Production. J. Chem. Technol. Biotechnol. 2009, 84, 63-68. [CrossRef]

79. Doyle, J.D.; Parsons, S.A. Struvite Formation, Control and Recovery. Water Res. 2002, 36, 3925-3940. [CrossRef]

80. Alamdari, A.; Rohani, S. Phosphate Recovery from Municipal Wastewater through Crystallization of Calcium Phosphate. Pac. J. Sci. Technol. 2007, 8, 27-31.

81. Stratful, I.; Brett, S.; Scrimshaw, M.B.; Lester, J.N. Biological Phosphorus Removal, its Role in Phosphorous Recycling. Environ. Technol. 1999, 20, 681-695. [CrossRef]

82. Desmidt, E.; Ghyselbrecht, K.; Monballiu, A.; Verstraete, W.; Meesschaert, B.D. Evaluation and Thermodynamic Calculation of Ureolytic Magnesium Ammonium Phosphate Precipitation from UASB Effluent at Pilot Scale. Water Sci. Technol. 2012, 65, 1954-1962. [CrossRef] [PubMed]

83. Desmidt, E.; Ghyselbrecht, K.; Monballiu, A.; Rabaey, K.; Verstraete, W.; Meesschaert, B.D. Factors influencing Urease Driven Struvite Precipitation. Sep. Purif. Technol. 2013, 110, 150-157. [CrossRef]

84. Dai, J.; Tang, W.T.; Zheng, Y.S.; Mackey, H.R.; Chui, H.K.; van Loosdrecht, M.C.; Chen, G.H. An Exploratory Study on Seawater-catalysed Urine Phosphorus Recovery (SUPR). Water Res. 2014, 66, 75-84. [CrossRef] [PubMed]

85. Tang, W.; Dai, J.; Liu, R.; Chen, G. Microbial Ureolysis in the Seawater-catalysed Urine Phosphorus Recovery System: Kinetic Study and Reactor Verification. Water Res. 2015, 87, 10-19. [CrossRef] [PubMed]

86. Castro, S. Flotación con Agua de mar. In El Agua de Mar en la Minería: Fundamentos y Aplicaciones; Cisternas, L., Moreno, L., Eds.; RIL Editores: Santiago, Chile, 2014; pp. 99-119. ISBN 978-956-01-0081-8.

87. Castro, S.; Laskowski, J.S. Froth Flotation in Saline Water. KONA Powder Part. J. 2011, 29, 4-15. [CrossRef]

88. Castro, S. Challenges in Flotation of Cu-Mo Sulfide Ores in Sea Water. In Proceedings of the 1st International Symposium, Water in Mineral Processing; Drelich, J., Ed.; SME: Englewood, IL, USA, 2012; pp. $29-40$.

89. Castro, S.; Lopez-Valdivieso, A.; Laskowski, J.S. Review of the Flotation of Molybdenite. Part I: Surface Properties and Floatability. Int. J. Miner. Process 2016, 148, 48-58. [CrossRef] 
90. Castro, S.; Laskowski, J.S. Depressing Effect of Flocculants on Molybdenite Flotation. Miner. Eng. 2015, 74, 13-19. [CrossRef]

91. Liang, J.; Deng, A.; Xie, R.; Adin, A. Impact of Seawater Reverse Osmosis (SWRO) Product Remineralization on the Corrosion Rate of Water Distribution Pipeline Materials. Desalination 2013, 311, 54-61. [CrossRef]

92. Cuzman, O.A.; Rescic, S.; Richter, K.; Wittig, L.; Tiano, P. Sporosarcina pasteurii use in Extreme Alkaline Conditions for Recycling Solid Industrial Wastes. J. Biotechnol. 2015, 214, 49-56. [CrossRef] [PubMed]

93. Le Corre, K.S.; Valsami-Jones, E.; Hobbs, P.; Parsons, S.A. Phosphorus Recovery from Wastewater Struvite Crystallization: A Review. Crit. Rev. Environ. Sci. Technol. 2009, 39, 433-477. [CrossRef]

94. Pratt, C.; Parsons, S.A.; Soares, A.; Martin, B.D. Biologically and Chemically mediated Adsorption and Precipitation of Phosphorus from Wastewater. Curr. Opin. Biotechnol. 2012, 23, 890-896. [CrossRef] [PubMed]

95. Gonzalez-Muñoz, M.T.; Rodriguez-Navarro, C.; Martínez-Ruiz, F.; Arias, J.M.; Merroun, M.L.; Rodriguez-Gallego, M. Bacterial Biomineralization: New Insights from Myxococcus-induced Mineral Precipitation. Geol. Soc. Lond. Spec. Publ. 2010, 336, 31-50. [CrossRef]

96. Smirnov, A.; Suzina, N.; Chudinova, N.; Kulakovskaya, T.; Kulaev, I. Formation of Insoluble Magnesium Phosphates During Growth of the Archaea Halorubrum distributum and Halobacterium salinarium and the Brevibacterium antiquum. FEMS Microbiol. Ecol. 2005, 52, 129-137. [CrossRef] [PubMed]

97. Van Paassen, L.A.; Daza, C.M.; Staal, M.; Sorokin, D.Y.; van der Zon, W.; van Loosdrecht, M.C.M. Potential Soil Reinforcement by Biological Denitrification. Ecol. Eng. 2010, 36, 168-175. [CrossRef]

(C) 2017 by the authors. Licensee MDPI, Basel, Switzerland. This article is an open access article distributed under the terms and conditions of the Creative Commons Attribution (CC BY) license (http://creativecommons.org/licenses/by/4.0/). 